Meta

Journal des traducteurs

Translators' Journal

\title{
A German Connection? Context-Description of Literary Translation Efforts in Southern Brazil
}

\section{Eva Wysk Koch}

Volume 35, numéro 3, septembre 1990

La traduction dans le monde hispanolusophone

URI : https://id.erudit.org/iderudit/003329ar

DOI : https://doi.org/10.7202/003329ar

Aller au sommaire du numéro

Éditeur(s)

Les Presses de l'Université de Montréal

ISSN

0026-0452 (imprimé)

1492-1421 (numérique)

Découvrir la revue

Citer cet article

Wysk Koch, E. (1990). A German Connection? Context-Description of Literary Translation Efforts in Southern Brazil. Meta, 35(3), 602-606.

https://doi.org/10.7202/003329ar d'utilisation que vous pouvez consulter en ligne. 


\section{A GERMAN CONNECTION ? CONTEXT-DESCRIPTION OF LITERARY TRANSLATION EFFORTS IN SOUTHERN BRAZIL}

EVA WYSK KOCH

Universidade Federal do Rio Grande do Sul, Brazil

\section{For Rüdiger}

During the past months readers, translators and potential translators in Southern Brazil could find at least some answers to basic questions in local and European publications. But 1987 was by far no year of outstanding achievements, as the III National Congress of Translators, dedicated to problems of teaching Translation, showed clearly with a few honourable exceptions. With regard to the translation of literary texts, the meeting in Porto Alegre, State of Rio Grande do Sul, proved once again that it is difficult to explain how to do something, when one does not really know what one holds in one's hands.

The two southernmost states of Brazil are an atypical and uncomfortable place for discussing literary translation. While the Portuguese-speaking general public still values fluency and familiarity of themes above anything else in a translated text, descendants of German immigrants (as long as they dominate the language of their forefathers and read), deviate from the national scenery by hoping for more courageous objectivations of allusions to German thought. Both expectations are equally distant from Walter Benjamin's ${ }^{1}$ proposal of attempting liberation of "pure language" by lastly converging verbalizations, which is not easily understood in spite of efforts of over a decade by a group of active Benjamin fans in São Paulo and more recently at the Federal University of Minas Gerais, in the center of the country.

There do exist, however, some recent "loving" translations (op. cit. p. 18) of German literature among us. I will try to present two distinct types without attempting to be representative.

I. Carlos Nejar ${ }^{2}$ revisited Goethe's Faust I (with the help of a former GoetheInstitut director) in a very intuitive way, so much so that the scenes chosen for his recreation seem to have really matured in the tropics, just as Benjamin saw the possibility of the revival of immanent tendencies of a work via love of language. Within a Benjaminian view of translation it is only correct that this Portuguese version of Faust be retranslated into German. But "Nichts erneuert so wie Vergessenheit"3.

Benjamin's dictum serves to present a wish for still deeper philological preparation of such a gifted translator as Nejar, also in view of renewed Brazilian attempts to understand A Linguagem do Fausto de Goethe, title of a book which summarizes Delton de Mattos' decades of reading Part $\mathrm{I}^{4}$. Perhaps one can say that Peter Horst Neumann's observation about the generalized lack of a sense for allusion at times of markedly allusive literary production 5 becomes conversely true for Brazil when post-graduate interests in the field of intertextuality start to dominate in 1987-88 as a consequence of Third World thirst for meaning ${ }^{6}$, while contemporary Brazilian literature continues to be much less 
polysemous than for example Anna Jonas' Das Frettchen (1985), Dürrenmatt's, Grass' or Böll's prose, not to speak of Arno Schmidt's.

Another quotation will have to explain this hypothesis. The most respected Brazilian literary critic António Cándido de Mello e Souza reinvited reflexion about "literature as art" versus "literature as science" by concluding a recent interview to the literary supplement of Jornal do Brazil with the statement "Para mim, a informação desencadeia a intuição." (For me, information starts intuition.)

For many readers in southern Brazil the novum is here the inverted order of intuition and information, ending thus - magister dixit - hopefully an extensive period of Neo-Impressionism in interpretation and literary criticism which maimed translators' efforts to the utmost.

It is here that ethnic minorities(y?) see(s) a slight chance of finally participating in the national discourse. Just a simple example. Once in a while one can still hear rural choirs in German immigration zones singing outdated evergreens such as

\footnotetext{
"Es waren zwei Königskinder,

Die hatten einander so lieb;

Sie konnten zusammen nicht kommen,

Das Wasser war viel zu tief."
}

Heinrich Böll's "Waschküchenliteratur" with its appeal to popular (even corny) referentials quotes this folksong at the end of metatextual chapter 2 of Die verlorene Ehre der Katharina Blum oder Wie Gewalt entstehen und wohin sie führen kann": "denn schliesslich gibt es auch Stockungen, Stauungen, Versandungen, missglückte Konduktionen und Quellen die 'zusammen nicht kommen können', ausserdem unterirdische Strömungen usw." (p. 9).

A teuto-Brazilian reader, normally ill at ease with Böll's highly polysemous prose, happily recognizes the structuring element "water" in the gully-gutter of power-nets, separating (metaphorically speaking) two admirable children of regal descent. Angrily, because identified with them, he observes, however, that "the" luso-Brazilian counterpart - with the translation " $(. .$.$) fontes 'incompatíveis' (...)" at hand - will never grasp the$ allusion to respectability, worse, laughs at tentatives to anchor shrill local voices in contemporary German literature and/or the Brazilian metropolitan discourse.

Forgive a further digression before rounding up this aspect of the old-new focus on interpreting and translation polysemous texts in Brazil. Not yet accepted as readingpartner by lusos, "the" teuto-Brazilian (in his dependency from Europe, reinforced by prejudice against Germanization in general and descendants of imported slave-substitutes in particular) will probably look for approval from the old homeland. Gladly he notices how a veteran germanist such as Walter Müller-Seidel pinpoints and denounces the origin of the theory of Kafka - texts' supposed univocity ${ }^{9}$, or how the Dutch periodical Poetica continues Theodor Verweyen's efforts in clarifying Brecht's and Grass' dialogue with Shakespeare's Coriolanus and each other ${ }^{10}$ by giving voice (among so many others) to Winfried Menninghaus, when he examines only apparent exotica like the inter-Italian panorama of Romeo and Juliet's affair and its different functions in pre-shakespearean times ${ }^{11}$. Most of all he will enjoy Erhard Dahl's article in Wirkendes Wort of July/August 198712 where the educator explains how a certain stubborn impressionism is to be officially overcome also at German Senior-High Schools by fostering "sensibility for textsignals, relations and interdependencies" among pre-university students, in order to improve an underdeveloped competence in the reception of "demanding" literary texts via stronger observation of the pole of emission (p. 230). Confounded, however, "the" teuto-Brazilian watches how BRD's cultural institutions around him will have nothing to 
do with such "innovations", explaining their preference for maintaining the local, in fact unsolidary, reading-status quo with the official interest in merely echoing the most frequently observed tendencies. Referentials again became a politicum. Confused by confusion he also learns from Karl Maurer ${ }^{13}$, editor of Poetica, that the Deutsche Forschungsgemeinschaft, highest research financing organ in the BRD which supported us in the past, had not deemed it justifiable up to March ' 88 to invite consultants in the field of Comparative Literature, having handed it over to mere germanists.

The last five years were so interesting because they permit to accompany the change of a reception-paradigm from various angles. António Gómez-Moriana's prefaces to his La subversion du discours rituel ${ }^{14}$ help explain the conflicting situation once combined with Luiz Costa Lima's contributions about the tradition of Brazilian literary criticism and mimesis to Der Diskurs der Literatur- und Sprachhistorie ${ }^{15}$. Following GómezMoriam's introduction one can see the always only partly bi-cultural teuto-Brazilian immerged in a potentiated conflict of socially regulated rituals of occupying signals of complex, paradoxal communication. Costa Lima in turn showed different ways of producing literary criticism in Brazil's XIXth century and characterizes among them the critic as a more or less autocratic judge, conscious - and/or unconsciously voicing opinions and necessities of dominant groups, - an institutionalized transcodifier with prescribed spectacles, if one takes the picture farther into translation. Sometimes still today unable to read the original, the "judge" organizes and orients the translation from his own, perhaps even chauvinistically biased repertory, but always - and because of it - in the interest of identifiable power-holders. He decides the range of filling in foreign verbal signs for others, in spite of being many times "diatopically, diachronically" and specially "diastratically" underinformed. To suggest corrections, also in our century and in a so-called pluralistic society, can be considered subversive, unless information, the most widespread and even bizarre, be democratically made available for attempts in polysemous translation.

II. While this more author-oriented, more generously informed translation is slow to arrive for lack of help from literary interpreters, or even to converge with the virtualities of the vernacular language, clever professionals prefer to avoid polysemous texts. It may not be too simplified to see the pronounced interest of Brazilian editors and translators in Hubert Fichte's (1935-1986) books also under this perspective. He will be the second example for recent "loving" translation of German authors in Brazil.

S. Fischer's project for editing Fichte's Die Geschichte der Empfindlichkeit ${ }^{16}$ in 19 parts, from which the seven central ones are nonexistent and the rest concerned with Germany, travels to Portugal, Brazil, Venezuela, Florida, the Caribbean Islands and Africa, is a transcultural undertaking of considerable courage. Four future paralipomena are destined to help the understanding. Within the here explored vein of battles about referentials, the recognition and translation of references to Brazilian customs, political events and religious practices of African origin are indeed a sager territory, seen from our pole. Marginalized as youngsters in Hitler-Germany as a fatherless semi-Jew, Fichte seems to have no existential shell to hide in. He was painfully conditioned for openness, living and writing transculturally and interdisciplinarily to an overwhelming extent, in opposition to the somehow skeptical articles published in Universitas ${ }^{17}$ about interdisciplinary efforts of the past. As his congenial interpreter Wolfgang von Wangenheim explains $^{18}$, Fichte's technique of interviews - solidary, redone, restudied, repeated ones -, breaks the shells also of his informants, creating a documentary literature of (in my opinion) never reached objectiveness. While Hans Magnus Enzensberger's Der kurze Sommer der Anarchie, Buenaventura Duruttis Leben und Tod (1972, translated in 1987, contextualized in a manuscript accepted for publication in 1986) maintains a captivating lightness with his collage of informants' conflicting quotations, Fichte brings about 
final uneasiness by the slowly emerging questions, making his informants and readers critical of themselves and the interviewer. Along Fichte's enculturation in unknown environments, initial enchantment with exotic practices becomes disillusion as - also while experiencing realities so unbourgeois - murderous power-fights come to the surface. But even when contradictory representation-habits relativize all mysticism, the vitality and consistency of the diverse allusive mechanisms transcribed surprise. How the History of Touchiness 19 will account for solidarity, treason and pressures, diminishing faiths, pure business and envy, is a challenge impatiently expected at this side of the Atlantic, together with the translation of all of Xango ${ }^{20}$. In the meantime there is O Orfanato, translated by Carlos Almeida Pereira for Editora Guanabara, Rio de Janeiro, in 1986. Fichte's Das Waisenhaus (1965/1977) starts the interdisciplinary inquiry by charging Christian churches for the lack of more consistent initiation (only the head, not the body), which in turn originates Versuch über die Pubertät (1974/1979), congenially translated by Zé Pedro Antunes 21 with a substantial postface which allows the reader to come to conclusions unassistedly, before listening to the translator's observations in order to start the second reading together with him.

Breaking shells, breaking taboos: body functions, sexuality and crimes are assumed in all forms; language shields are undone to an extent that requires glossaries (Wangenheim). But traumata, memories and details can be vomited just as during purifying ceremonials described in Etnopoesia ${ }^{22}$, an informative selection of interviews in tension, oriented for the Brazilian translation (by Cristina Alberts and Reny Hernandes) by the author himself, together with DAAD lecturer Wolfgang Bader who also wrote the preface. One astounding discovery: "Conscience is broken chemically" (op. cit., p. 184).

Fichte has a lot to say to Iberoamericans, to Anthropology, Ethnology, Humanity. Transcodifiers do well in participating in the History of Touchiness since, according to the author, "both, bisexualism and bicontinentalism, are conditioned by repression." (op. cit., p. 284)

III. Both types of texts, the more polysemous and the less ones, require transparent work on their referentials by the translator. While the last type may lead to a greater amount of synchronic information about the presented epoch in all its manifestations, the extent of retroactive research necessary for the former, though not encouraged by a great translator like Böll ${ }^{23}$, may lead to experiencing the chemistry of world literature, similar to the one the Jena Romantics knew, when they projected their telos of "chaos" or "endless plenitude". It is among them and their readers that the Greeks, Shakespeare, the French and the Spaniards come to word, allowing to limit for example Allan Bloom's 24 denunciation of Germanization in (the) America(s), - once research in Weltliteratur is no longer hindered by politics.

On the other hand, literature of anthropologic concern like Fichte's calls attention to the not often enough studied vein of popular metaphorization among us. It is from here that pictorial vigour can contribute to profiling continental characteristics. And translators want to be part of it.

\section{NOTES}

1. Walter Benjamin (1971): "Die Aufgabe des Übersetzers", Gesammelte Schriften, "Vorwort zu Charles Baudelaires Tableaux parisiens", Frankfurt a.M., Suhrkamp. pp. 9-21.

2. Carlos Nejar (1987): Fausto, Porto Alegre, Tchê! Editora Ltd.

3. Nothing renews as much as having been forgotten. Op. cit., vol. III, p. 287.

4. Delton de Mattos (1986): A Linguagem do Fausto de Goethe, Brasilia, Thesaurus Editora.

5. Peter Horst Neumann (1980): "Das Eigene und das Fremde. Über die Wünschbarkeit einer Theorie des Zitierens", Akzente, München, Carlttanser, 27:4, August, p. 304.

6. In opposition to German weariness. 
7. A.C. de Mello e Souza (1988): Ideias, Rio de Janeiro, March 19, p. 5.

8. Gutersloh, Bertelsmann Reinhard Mohn OHG (1975): pp. 8-9. A Honra Perdida de Katharina Blum ou: possivies origens e caminhos da violencia, trans. Klaus Schell, Rio de Janeiro, Ed. Artenova, p. 9.

9. Walter Müller-Seidel (1986): "Die Deportation des Menschen. Kafkas Erzählung 'In der Strafkolonie' im europäischen Kontext", in Deutsche Bücher (1987), Amsterdam, Rodopi, 2, pp. 121-124.

10. Theodor Verweyen (1984): "Die Tragödie des Coriolanus" bei Brecht und Grass oder über die Verarbeitung literarischer Modelle", Poetica, Amsterdam, 16:3-4, pp. 246-275.

11. Theodor Verweyen (1987): "Zwischen Bandello und Shakespeare: Pierre Boiastuaus Romeo und JuliaVersion", Poetica, 19:1-2, pp. 3-31.

12. Erhard Dahl (1987): "Überlegungen zu einem 'wissenschaftspropaedeutischen' Literaturunterricht", Wirkendes Wort, 37:4, pp. 224-233.

13. Karl Maurer (1988): "Durch Wachstum klein. Das Schicksal der Vergleichenden Literaturwissenschaft", Frankfurter Allgemeine Zeitung, 64, March 16, p. 35.

14. Antonio Gomez-Moriana (1985): La subversion du discours rituel, Québec, Éditions du Préambule, pp. $7-17$.

15. B. Cerquiglini and H.U. Gumbrecht, eds. (1985): Der Diskurs der Literatur und Sprachhistorie. Wissenschaftsgeschichte als Innovationsvorgabe, Frankfurt a.M., Suhrkamp, pp. 367-404, $511-536$.

16. Propaganda material edited by G. Lindeman and T. Teichert in collaboration with Lenore Mau, July 1987.

17. Marksteine (1988): Ausgabe der Zeitschrift für Wissenschaft, Kunst und Literatur, Stuttgart, Wissenschaftliche Verlagsgesellschaft, 43:1-2, Jan.-Feb., pp. 4-20.

18. Wolfgang von Wangenheim (1980): Hubert Fichte, München, Beck, Verlag Edition Text und Kritik (especially chapter III), pp. 139-168.

19. Rather than "Sensibility" or "Sensitivity", because of the presence of Irritation?

20. Hubert Fichte (1976): Die afroamerikanischen Religionen. Bahia, Haiti, Trinidad, Frankfurt a.M., S. Fischer.

21. Hubert Fichte (1986): Ensaio sobre a puberdade, trans. ZÉ Pedro Antunes, São Paulo, Brasiliense

22. Hubert Fichte (1987): Antologia poética das religiöes afro-americanas, trans. Cristina Alberts and Reny Hernandes, with the translation of Fichtes's Conference at the Frobenius Association (1977), São Paulo, Brasiliense.

23. Manuscript accepted for publication in 1987.

24. Allan Bloom (1987): The Closing of the American Mind. How Higher Education has Failed Democracy and Impoverished the Souls of Today's Students, New York, Simon \& Schuster. 